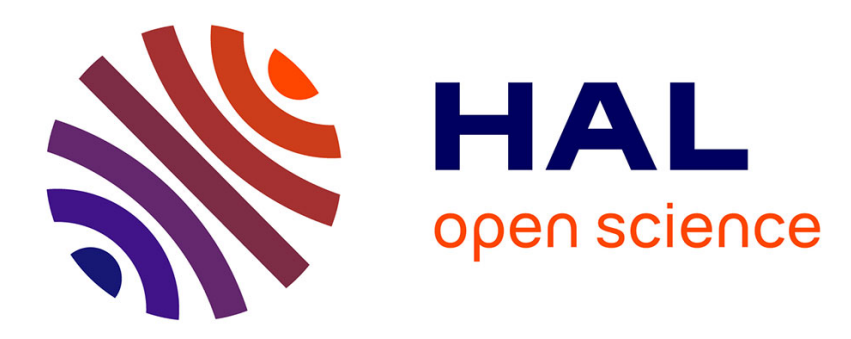

\title{
Shielding methods for insulators and other components
} T.W. Aitken, R. Thorn

\section{To cite this version:}

T.W. Aitken, R. Thorn. Shielding methods for insulators and other components. Revue de Physique Appliquée, 1977, 12 (10), pp.1517-1519. 10.1051/rphysap:0197700120100151700 . jpa-00244359

\section{HAL Id: jpa-00244359 https://hal.science/jpa-00244359}

Submitted on 1 Jan 1977

HAL is a multi-disciplinary open access archive for the deposit and dissemination of scientific research documents, whether they are published or not. The documents may come from teaching and research institutions in France or abroad, or from public or private research centers.
L'archive ouverte pluridisciplinaire HAL, est destinée au dépôt et à la diffusion de documents scientifiques de niveau recherche, publiés ou non, émanant des établissements d'enseignement et de recherche français ou étrangers, des laboratoires publics ou privés. 


\title{
SHIELDING METHODS FOR INSULATORS AND OTHER COMPONENTS
}

\author{
T. W. AITKEN and R. THORN
}

Daresbury Laboratory, Science Research Council, Daresbury, Warrington WA4 4AD, England

\begin{abstract}
Résumé. - On décrit les quatre isolateurs principaux et la technique de protection électrostatique des composants de la machine pilote.

Abstract. - The four main insulator and component shielding techniques used in the pilot machine are described. These range from simple grading for drive shafts to double screened enclosures for the shielding of integrated circuits.
\end{abstract}

1. Introduction. - One of the most important projects which has been undertaken at Daresbury has been the testing of shielding methods for insulators and other components for the NSF tandem. Early work on this $[1,2]$ has been incorporated into the design of the pilot machine and tested over a period of years. Many additional new devices have been developed and installed and their performance has been assessed.

Some idea of the severity of the surges which occur inside a stack following a terminal breakdown is shown in figure 1. This photograph was taken at extremely high gradient and shows almost every spark gap lit up. Some have multiple sparks indicating that an extremely fast wavefront was present. It is this sort of hostile environment which makes the development of shielding methods so essential.

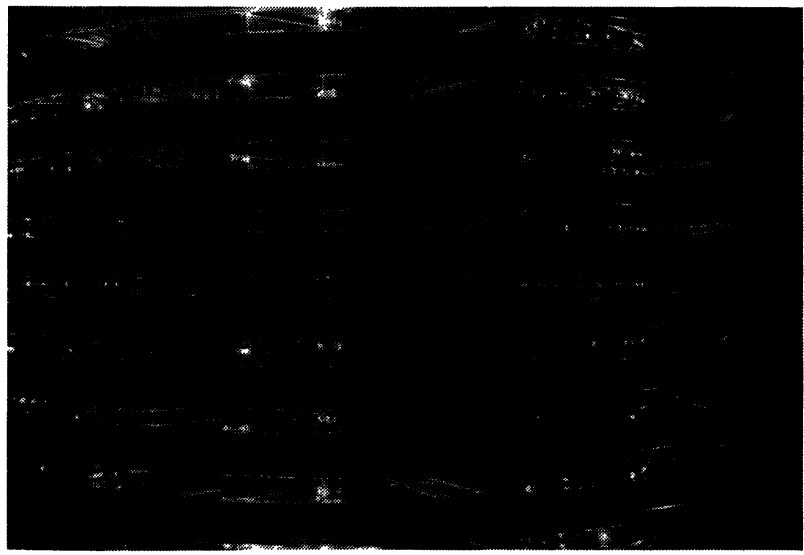

FIG. 1. - Spark gaps in action in the pilot machine stack.

2. Shielding Methods. - Shielding methods in the pilot machine can be divided into four main categories and these are now discussed.
2.1. Stack Grading. - Insulating materials such as cooling tubes, control rods and drive shafts running through the graded stack can survive surges provided there is grading at reasonable intervals (every $800 \mathrm{~mm}$ in the pilot machine) and the materials are very strong electrically in their own right. Materials with voids such as extruded rod, glass fibre light guides and glass reinforced nylon should be avoided where very high gradient is used. Figure 2 shows a drive shaft section with the profiled bearing housing at the top, and two nylon pipes carrying freon cooling liquid. The freon is pressurized externally with $\mathrm{SF}_{6}$ gas. It is important that at the ends of the shaft or tubes there is electrostatic field shaping to minimize the electric field along the surface at the contact point.

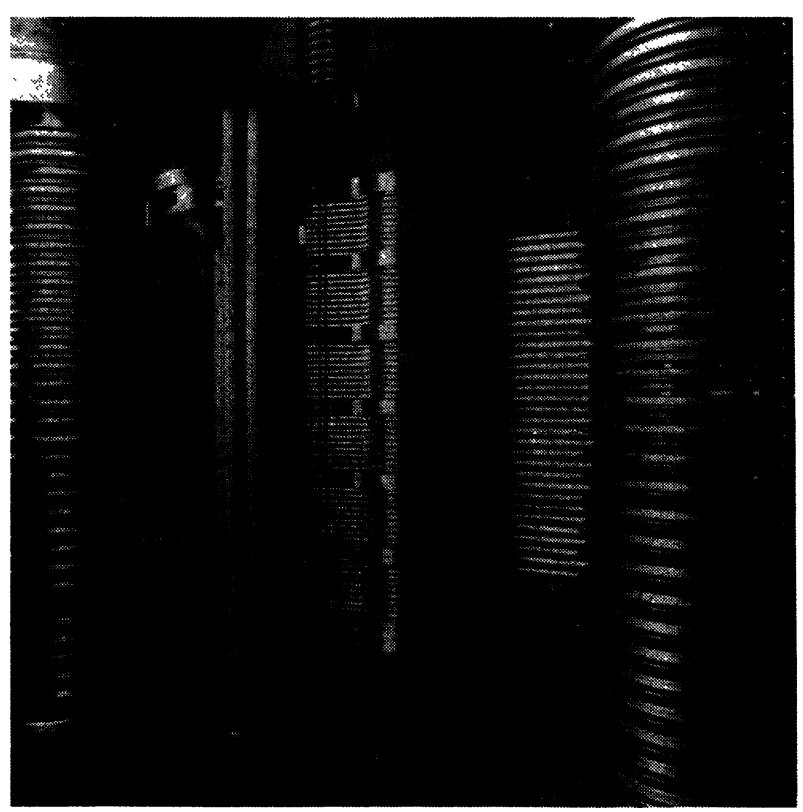

Fig. 2. - Drive shaft and freon cooling tubes. 
2.2. Strong Field Shaping with Continuous SURROUNDING SPARK GAP. - This is probably the most important concept of all. The insulator or component is protected from high localized electric fields by shaping the field around it so strongly that it cannot be distorted by any external disturbances. The spark gap limits the maximum internal field to a safe value. This method is used on the support leg insulators, the laddertron insulating links and the column resistors. Figure 3 shows the resistor and leg systems.

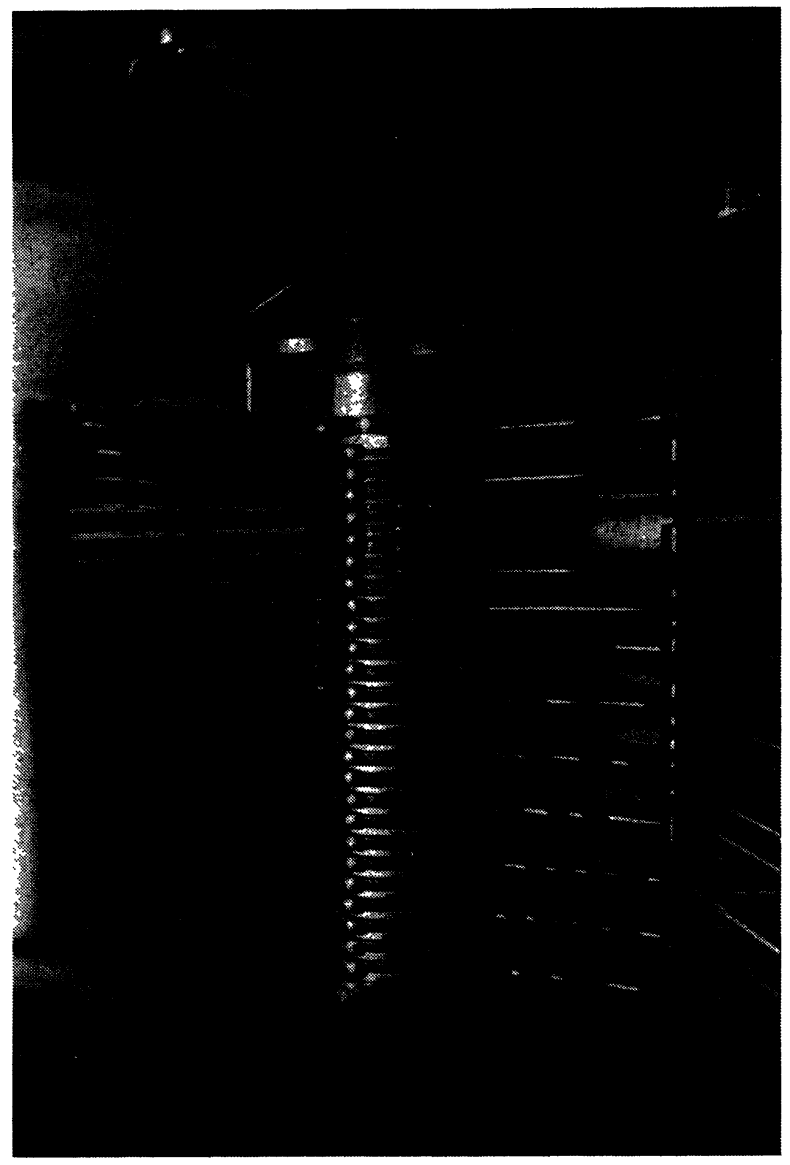

FIG. 3. - Grading resistor and support leg spark gap systems.

Over a period of three years there have been no failures or measurable change in resistance in any of the 750 Welwyn metal oxide resistors used, nor any damage to the 600 glasses used despite the very high gradients reached and the many discharges experienced. About 150 of the glass insulators are made from soda glass which is known to have a much inferior electrical strength compared to the borosilicate glass used in the rest of the stack. Such is the power of this protection method that none of these soda glasses has been damaged. This technique is also applied to the tube insulators and its individual resistor chain.

2.3. Isolation by Low Capacitance Series ResisTOR. - Coaxial filters which protect the $60 \mathrm{kV}$ laddertron supplies, see figure 4 and stack current monitors from direct sparks have been successfully develo- ped [3]. The filter is basically a lossy coaxial transmission line which attenuates transients to a tolerable level. Input transients are limited by a spark gap. In the case of the $60 \mathrm{kV}$ filter this has been tested with $1 \mathrm{MV}$ surges in $\mathrm{SF}_{6}$ from a Marx generator directly on to its input terminal and has successfully survived many direct spark hits in operation in the machine.

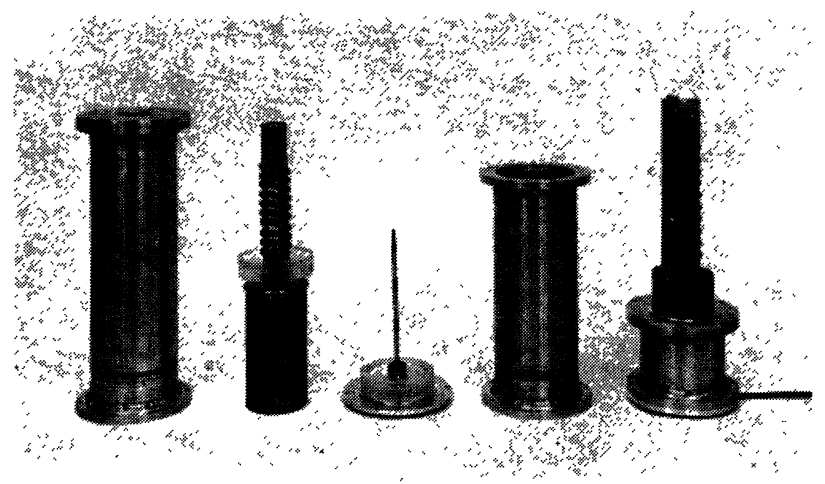

FIG. 4. $-60 \mathrm{~kW}$ coaxial surge filter.

2.4. SCREENING IN METAL BOXeS WITH FILTER FEEDTHROUGHS. - Two degrees of screening of electrical equipment are used. For drive motors alternators and equipment such as high voltage supplies which have a high natural tolerance to voltage surges each item and its wiring is single screened. The screening is divided up into many units and wiring goes from one to another through filters. Were a signal or control wire has to come out of the screening it comes out via one of the filters described in section 2.3.

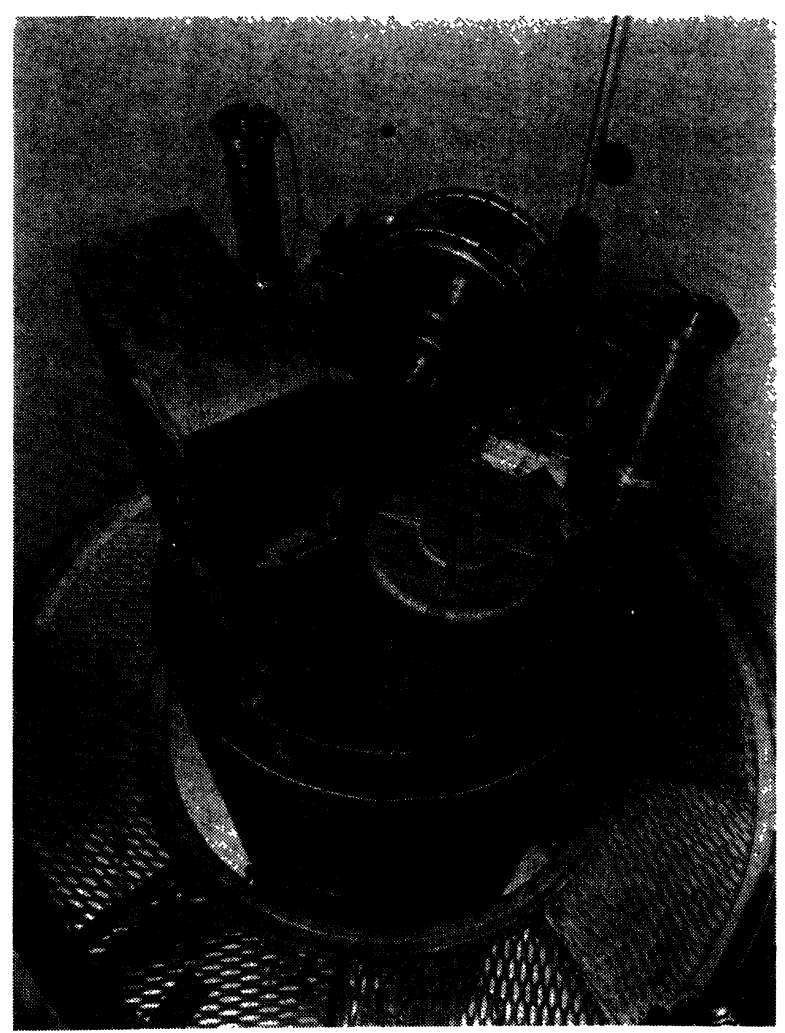

FIG. 5. - Double screened electronic crate. 
For sensitive electronic equipment double screening is provided [4]. This in effect is screening which sits inside the single screening just described. Wiring enters this inner enclosure again only through filters. Figure 5 shows a typical double screened crate. The electromagnetic fields from intense sparks are filtered by the two metal screens and external wiring is filtered at least three times before reaching inside the inner screening. Integrated circuits MOSFET transistors and other surge sensitive components can exist inside this environment without damage provided these rules are obeyed. There has been no surge damage to any of the screened equipment in the pilot machine in about 3 years of operation.

\section{References}

[1] Collins L. E., Howe F. A. and Thorn R., Proc. Int. Conf. on the Technology of Electrostatic Accelerators, Daresbury (1973) 121.

[2] Aitken T. W., Proc. Int. Conf. on the Technology of Electrostatic Accelerators, Daresburv (1973) 147.

[3] Johnstone W. T. and Charlesworth T. R., Nucl. Instrum. Methods 131 (1975) 549.

[4] Horrabin C. W., Johnstone W. T. and Spurling K., Daresbury Laboratory Report DL/NSF/R13 (1975). 